Policies for a Just Society 
By the same author

The Good City (with Paul Soto)

The Politics of Poverty

A Radical Agenda 


\title{
Policies for a Just Society
}

\author{
DAVID DONNISON
}




\section{$\approx$}

\section{(C) David Donnison 1998}

All rights reserved. No reproduction, copy or transmission of this publication may be made without written permission.

No paragraph of this publication may be reproduced, copied or transmitted save with written permission or in accordance with the provisions of the Copyright, Designs and Patents Act 1988, or under the terms of any licence permitting limited copying issued by the Copyright Licensing Agency, 90 Tottenham Court Road, London W1P 9HE.

Any person who does any unauthorised act in relation to this publication may be liable to criminal prosecution and civil claims for damages.

The author has asserted his rights to be identified as the author of this work in accordance with the Copyright, Designs and Patents Act 1988.

First published 1998 by

MACMILLAN PRESS LTD

Houndmills, Basingstoke, Hampshire RG21 6XS

and London

Companies and representatives

throughout the world

ISBN 978-0-333-65645-7 ISBN 978-1-349-26058-4 (eBook)
DOI 10.1007/978-1-349-26058-4

A catalogue record for this book is available

from the British Library.

This book is printed on paper suitable for recycling and made from fully managed and sustained forest sources.

$\begin{array}{cccccccccc}10 & 9 & 8 & 7 & 6 & 5 & 4 & 3 & 2 & 1 \\ 07 & 06 & 05 & 04 & 03 & 02 & 01 & 00 & 99 & 98\end{array}$

Editing and origination by Aardvark Editorial, Mendham, Suffolk 


\section{Contents}

List of Figures and Tables

vi

Preface

Introduction

\section{PART I}

\section{A Disintegrating Society}

1 Hardship: facts and meanings

2 Does poverty matter?

3 Can anything be done?

4 Traditions of resistance

\section{PART II}

\section{Act Local}

5 Citizens and civic leaders

6 Skills, work and money

7 Safety

8 Mainstream services

9 Egalitarians and greens

10 For baffled citizens

\section{PART III}

\section{Towards Conclusions}

11 By what authority?

12 Conclusion

Bibliography 


\section{List of Figures and Tables}

\section{Figures}

1.1 Individuals below half-average income, 1961-91, by family type

1.2 Children living in poverty, 1979-1991/92 10

1.3 Real incomes, 1961-91 (after housing costs) 11

1.4 Trends in income inequality 15

1.5 Unemployment rates for different ethnic groups, 1984-95 16

1.6 Child poverty by family type, 1979-1991/92. Percentage in households with below half-average income

2.1 The decline in reading standards in Buckinghamshire, 1975-91 for all 7-8-year-old schoolchildren (Chiltern Reading Test scores)

2.2 Life expectancy and income distribution in different countries around 1981

3.1 Trends in inequality for different countries of the European Union

3.2 Death rates by social class in Sweden and in England and Wales

5.1 Potential responses to prolonged poverty and hardship

7.1 Prison populations: an international comparison. Rate per 100,000 recorded crimes

7.2 Variations in anxiety by ethnic origin. Percentage feeling 'very worried' or 'very unsafe'

7.3 What happens to offenders. Attrition within the criminal justice system

\section{Tables}

1.1 Participation in full-time education of different ethnic groups, by age, spring 1994

3.1 Standardised unemployment rates in OECD countries

4.1 Attitudes to public spending, 1995 


\section{Preface}

This book was inspired by some work I did for the Commission on Social Justice set up by the late John Smith when he was leader of the Labour Party. Their first statements dealt mainly with action to be taken on a national scale. How about the local scale?, I asked. The just city or the just village? What would they be like? Can such places be created? The Commission welcomed these questions, and, with some help from the Rowntree Charitable Trust and lots more from people doing enterprising things at local levels, I eventually produced a pamphlet called Act Local, published for the Commission by the Institute of Public Policy Research. During the following months many other people took up issues of social justice and poverty, encouraged by reports such as those produced by the Commission and the Rowntree Foundation, and spurred on by their own experience of the growth of poverty and the strains it was imposing on people and public services. I found myself repeatedly asked to contribute to conferences and other discussions and decided it might be more helpful if I developed the ideas in my pamphlet at greater length. Meanwhile it was becoming increasingly clear that, whoever won the next general election, a movement for social justice would have to be rebuilt from the ground up. This book is my attempt to help those engaged in that cause.

Some of my readers will be busy people with urgent practical tasks, some will have a more reflective approach to these questions and others will have both. I have tried to write for all of them. Each chapter concludes with a summary of the main things I learnt by writing it, and the final chapter contains a summary of the whole work, with pointers to the chapters in which these brief statements are developed at greater length. I hope that will enable people to skip and dip their way through the study if that is all they have time for, but I would not have written a book if I did not believe the whole thing to be worth reading. 
I have had generous help from many people - some working in the field and others in the academy. Since it would be impossible to name them all, I mention only those whom it would be intolerable to omit: the Gulbenkian Foundation, for covering the costs of my work; John Benington, Michael Geddes and their colleagues in the Local Government Centre at the Warwick Business School, which was my main base for this project; Ivan Turok and others in Glasgow University's Centre for Housing Research and Urban Studies, my other work base; Gerry Stoker at the University of Strathclyde for helpful comments on the whole book; Andrew McArthur and Keith Hayton in that University's Planning Centre, Neil Jameson at the Citizen Organising Foundation, Gary Craig at Humberside University, Pete Alcock at Sheffield Hallam University, Doreen Massey in her capacity as Editor of Soundings, Quintin Oliver and Fiona Macmillan, particularly for help in Northern Ireland. Contributions from many other friends and colleagues can be glimpsed in the references quoted throughout the book. Equally important has been the help of politicians, professional workers and community activists working in many parts of Britain and Ireland. My warmest thanks to them all.

In this book, as in everything else I do, I have constantly exchanged ideas and drafts with Kay Carmichael, my comrade and collaborator.

\section{Acknowledgements}

The author and publishers wish to thank the following for permission to use copyright material: the Controller of HMSO and the Office for National Statistics for material from Social Focus on Ethnic Minorities. Crown Copyright 1996 and Routledge for the use of three figures from Richard Wilkinson, Unhealthy Societies.

Every effort has been made to trace all the copyright holders but if any have been inadvertently overlooked the publishers will be pleased to make the necessary arrangement at the first opportunity. 


\section{Introduction}

A generation ago, when the terms 'first world' and 'third world' were coined to distinguish the richest from the poorest nations, Westerners had a crude understanding of the meaning of this distinction. In third world cities they expected occasional riots and politically motivated violence, they expected to see extremes of wealth and poverty with homeless beggars on the street, and to hear of casual brutality associated with prostitution and drugs. In their own cities they were generally safe from these things.

Not any more. That description would now apply equally well to London, Belfast, New York and many other cities of the West. Here in Britain these are not the only changes which people find worrying. There appears to have been a growth in football hooliganism, and in attacks on elderly people and teachers. There are dangers for which new names have been coined: 'road rage' and 'neighbours from Hell'. There seems to be more violence against children, and more violent crime of every kind, ranging from robberies to occasional, horrific massacres. Human relationships seem to be turning brutal.

The authorities to whom people used to look for protection and leadership in times of trouble are themselves becoming corrupted. Politicians take money for asking questions in Parliament; the Prime Minister sells to tycoons the opportunity for dining with him; the bosses of big monopolies which used to be thought of as public services award themselves vast increases in pay; the perpetrators of sexual abuses against children are often priests or staff of the agencies created to care for the nation's most neglected and vulnerable youngsters. No wonder the opinion polls show declining respect for leaders of most kinds. 
Whether our moral standards are decaying or not, there is certainly greater confusion than there used to be about what these standards should be. Lone parenthood, gay and lesbian weddings, the use of drugs - practices which some deplore - are enthusiastically advocated by others. This confusion extends beyond questions of right and wrong to judgements about many other things. Buildings which won prizes for their designers are pulled down a few years later because people find them impossible to live in. Piles of bricks, dead animals, human faeces and other works bought with public money for prestigious art galleries often sit there in lonely isolation because, once the first public curiosity has been satisfied, so few people want to see them. As for music, many are appalled by the incitement to violence and murder to be heard daily in some of the most widely sold 'gangsta rap' recordings.

A lot of people are dismayed by these developments. Some of them feel they should get together with their neighbours and do something to resist the drift towards social disintegration which they see all around. But what can they do? And with whom? This book is written for these people by someone who shares their dismay and bafflement, and brings to the task no confident prescriptions - only some ideas learned mainly from others who are trying to resist forces which seem to be dividing and brutalising our country.

It is upon the local scale of action - that of the neighbourhood, the town and the city - that I shall focus, but not because these local arenas are the places where divisive trends, now to be seen on a worldwide scale, can be most effectively resisted. Much of the action needed must be taken at national and, increasingly, international scales. That calls for another book. But a great deal must also be done on a local scale, for there are people and places now so excluded from the mainstream of their society that they will never find a way back into it unless special steps are taken to help them. Meanwhile the prospects for effective resistance at larger, national, scales of action are not good - for reasons which I shall explore. Political leaders will not regain a robust determination to resist the forces which are dividing our society unless they sense that they are speaking for broader popular movements. If reformers sit back and wait for their friends to gain power in Parliament nothing much will change. Resistance movements will have to be rebuilt from the ground up by people who deplore what is happening - people who rediscover traditions of local civic action, too long neglected, which used to be familiar in this and many other countries. 
When and why did things go wrong? Indeed, was there ever a golden age when things were going well? It has become fashionable to describe Britain during the years following the Second World War as passing through a period of social consensus, built on the comradeship achieved during the Blitz. A 'welfare state' based on universal principles which provided the same services for everyone was founded, and a high degree of equality was achieved. Most of this story is a myth - an important myth celebrating ideals we do not want to forget - but a myth nevertheless, fashioned as a contrasting backdrop against which to portray the harsher trends of recent years. ${ }^{1}$ There have been changes during these years which stem from the fact that Western countries are passing through a difficult time as they lose their dominant position in the world. This phase, beginning in the 1970 s and gathering speed in the late 80 s, has been a particularly bruising experience for the British. Until the 1970s, the more highly developed capitalist countries were gradually giving their citizens greater equality of incomes and wealth, more equal living conditions and greater civil and social rights. ${ }^{2}$ Thanks to full employment and to the confidence created by continuing economic growth, thanks to legislation enforcing minimum wages and protecting workers' rights, and thanks to a steadily growing array of social services, a social contract was being created which provided help for the youngest and the oldest citizens that was made possible by the contributions of those in the prime of life. It was a contract between the generations which helped to protect people in need at any stage of their lives.

This contract has not been completely abandoned, but from the mid-1970s its development was first checked, then reversed. Britain led a movement, now to be seen in many other countries, towards greater inequalities. Since then, 'poverty' - the word I shall often use to summarise the trends I am talking about - has been increasing, and increasing more dramatically in Britain than elsewhere. The first chapter in this book explains the issues it deals with by considering the meanings of some of the words - poverty, inequality, exclusion used in the debate, and by setting out the main facts which these words describe.

Do the divisive trends now at work matter? And to whom? Some people accept that poverty has been increasing but are not moved by that. They don't care. I consider their standpoint in Chapter 2. If they are right, this book should stop there. 
Can anything be done to change things? If so, how much of that action can be taken at a local level? There are people who accept that poverty has increased, and that it matters, but they are sceptical about the possibility of doing anything about it - particularly at a local scale. The more pessimistic of them believe that no solution can be found for such problems - perhaps quoting from the Bible: 'The poor ye have always with you' although in fact, the prophets of the Old Testament had some more forceful and hopeful things to say about the rights of the poor. The problems, the pessimists believe, arise from human defects. The individual may escape from these, but society as a whole cannot. Meanwhile, more optimistic people believe that poverty can be reduced, but only by creating a healthy, prosperous economy. Once that has been achieved, increasing wealth will filter down to everyone. Until then, action designed to reduce poverty will only make things worse. What we need are wealth-creating policies, not povertyreducing policies. I shall discuss both standpoints in Chapter 3. Once again, if they are right there is no point in going further.

The questions I have posed evoke the standard responses of those who have contested progressive arguments from the French Revolution onwards. Albert Hirschman reviews these responses, and their progressive counterparts, in The Rhetoric of Reaction. ${ }^{3}$ I will deal with them first in Chapter 3, and then throughout the book.

If we do have a problem - a problem which matters and which can be effectively tackled ('solved' may be too optimistic a word) - the next questions to ask must be about the traditions we can draw on for that purpose. What movements, armed with what ideas, can help Britain and other Western societies to resist and reverse these divisive trends? These are the questions addressed in Chapter 4 which concludes the first part of this book.

Part II deals with action - the things which can be done at a local scale to resist the forces which are breaking up our society. To do that, we must rebuild a tradition of robust and credible civic leadership in which citizens feel they play a part. The old bureaucratic forms of government we used to rely on cannot be recreated: that kind of power has been seeping away in private and public sectors alike. People are therefore working out new ways of getting things done which involve larger numbers of citizens, call for the mobilisation of a wider range of influences, and demand new kinds of leadership. The second part of this book starts with a chapter on 'Citizens and Civic Leaders', which draws on the experience of both. Thereafter I 
shall assume that any major new departure in policy must start by involving the people who will be most affected by it and listening to what they say.

The following chapters address problems in the order in which they are usually posed by people living in the communities which suffer most from the trends of our times. First come 'Skills, Work and Money' in Chapter 6; then 'Safety' in Chapter 7.

Next comes a chapter - the longest in the book - on 'Mainstream Services'. It does not deal in detail with the steps which can be taken by every department of government to reduce poverty. That job has been well done in reports I shall refer to. Mine will be an essay on the main strategies required, illustrated with examples from various services and many different places.

The hardships which result from growing inequality are a central feature of the problems encountered in most fields of public policy. But they are not the only feature. The other, to which growing attention is at last being paid, is the demands which our way of life make upon the earth's resources and the sustainability of that way of life. The two debates - about social justice and sustainability - are usually carried forward in different circles and discussed in different documents. But neither issue can be tackled effectively unless they are brought together, and the contradictions between them confronted and resolved. Chapter 9, 'Egalitarians and Greens', makes a start on that task.

Although I shall try to write like a democrat in ways which anyone can understand, this book is designed mainly for people who are in some way involved in our system of governance. Whether as politicians, administrators, community activists, private sector leaders or observers of their activities, they know the ropes to some extent. If provoked to act by something that is happening in their city or neighbourhood they have some idea where to begin. But there are many other people, equally provoked, who have no idea where to begin. Chapter 10, 'For Baffled Citizens', speaks particularly to them.

That concludes this part of the book which is the engine room of the whole work. Part III begins with a pause for reflection on the nature of the task undertaken here. What kind of an enterprise is this? By what authority does anyone tell their fellow citizens how their society should be run? And how, if at all, may the answers to these philosophical questions affect the day-to-day work of those involved in local governance? These are the issues explored in Chapter 11. 
That discussion provides a launching pad for the final chapter in which I summarise the main arguments of the whole book. I show where these brief statements have been developed at greater length in earlier chapters, and discuss their broader implications for those working at local scales of action to reverse the divisive tendencies now to be seen in Britain and other Western countries.

\section{Notes}

1 Howard Glennerster (in British Social Policy Since 1945, Oxford, Blackwell, 1995) and Nicholas Timmins (in The Five Giants: A Biography of the Welfare State, London, HarperCollins, 1995) present excellent histories of social policy and the welfare state in Britain.

2 For evidence about the changing distributions of income and wealth, see the Reports of the Royal Commission on the Distribution of Income and Wealth - for example, Third Report on the Standing Reference (Cmnd 6999, London, HMSO, 1977). For a history of the worldwide economic and political changes creating what he calls the 'golden age' of Western capitalism in the post-war years and then bringing it to an end, see Eric Hobsbawm's Age of Extremes (London, Michael Joseph, 1994).

3 Albert O Hirschman, The Rhetoric of Reaction: Perversity, Futility, Jeopardy, Cambridge, Mass., Harvard University Press, 1991. 